See discussions, stats, and author profiles for this publication at: https://www.researchgate.net/publication/286976018

\title{
Biosystems Engineering of Prokaryotes with Tumor-Killing Capacities
}

Article in Current pharmaceutical design · December 2015

Dol: 10.2174/1381612822666151210123752

CITATIONS

2

4 authors:

29. Ebuzer Kalyoncu

Bilkent University

5 PUBLICATIONS 13 CITATIONS

SEE PROFILE

(A) Alper Devrim Ozkan

Bilkent University

33 PUBLICATIONS 313 CITATIONS

SEE PROFILE
READS

210

Tolga Tarkan Ölmez

Yale University

14 PUblicATIONS 63 CITATIONS

SEE PROFILE

Omer Faruk Sarioglu

Bilkent University

15 PUBlications 95 Citations

SEE PROFILE 


\title{
Biosystems engineering of prokaryotes with tumor-killing capacities
}

\author{
Ebuzer Kalyoncu ${ }^{1,2}$, Tolga T. Olmez ${ }^{1,2}$, Alper D. Ozkan ${ }^{1,2}$ and Omer F. Sarioglu ${ }^{1,2, *}$ \\ ${ }^{1}$ Institute of Materials Science \& Nanotechnology, Bilkent University, 06800, Bilkent, Ankara, \\ Turkey; ${ }^{2}$ UNAM-National Nanotechnology Research Center, Bilkent University, Ankara 06800, \\ Turkey
}

\begin{abstract}
Certain bacteria selectively attack tumor tissues and trigger tumor shrinkage by producing toxins and modulating the local immune system, but their clinical utility is limited because of the dangers posed by systemic infection. Genetic engineering can be used to minimize the risks associated with tumor-targeting pathogens, as well as to increase their efficiency in killing tumor cells. Advances in genetic circuit design has led to the development of bacterial strains with enhanced tumor-targeting capacities and ability to secrete therapeutics, cytotoxic proteins and prodrug-cleaving enzymes, which allows their safe and effective use in the treatment of tumors. The present review details the recent advances in the design and application of these modified bacterial strains.
\end{abstract}

Keywords: Synthetic biology, cancer therapy, live vaccines, prodrug cleavage, Salmonella, Clostridium, Bifidobacterium

*Address correspondence to this author at UNAM-Institute of Materials Science \& Nanotechnology, Bilkent University, 06800, Bilkent, Ankara, Turkey; Tel: 90-312-2903507; Fax: 90-312-2664365; E-mail: sarioglu@ bilkent.edu.tr 


\section{INTRODUCTION}

The parasites and commensals of the human body are uniquely suited to survive in an environment that is hostile to any other form of life: having evolved in parallel with the mammalian immune system, these organisms are capable of avoiding the native defense mechanisms of their host and modulating its physiological responses to ensure their dispersal and reproduction. In addition, human parasites are often specific to a limited number of organs or tissues, with some targeting different tissue types at different stages of their life cycle. As such, they must identify and selectively infiltrate one or more target tissues to maximize their chances of survival - a goal that they share with various therapeutic delivery vesicles, which are inferior in their targeting performance and may benefit much from imitating their natural, parasitic counterparts. Although their activities are ordinarily detrimental, the sensitivity of human pathogens to tissue metabolic activity, in conjunction with their natural ability to evade the immune system, makes them ideal models for the development of novel therapeutic strategies against cancer and other diseases.

While delivery agents often use antibodies and similar proteins for selective targeting, an alternative approach proposes the use of pathogens as anticancer agents, utilizing the natural propensity of bacteria such as Salmonella and Clostridium to preferentially localize in tumor tissues [1]. Genetic engineering methods can be used to modulate the toxin production capacities and further augment the tumor-killing efficiency of these bacteria, creating biological anticancer agents that can be administered to eliminate tumors with minimal damage to the rest of the body [2]. While conventional delivery agents suffer from issues such as limited shelf-lives, high production costs, batch-to-batch variance, low circulation times, accumulation in non-specific tissues, immunogenicity and potential acquisition of drug resistance by cancer cells, tumor-killing bacteria can be used as a more reliable alternative for cancer targeting, or serve as a complementary therapy to increase the efficiency of well-established treatments [3-8].

The present review will detail recent efforts in the engineering of bacteria for the treatment of cancer, with emphasis on the mechanisms by which pathogens localize in tumor environments, 
bacterial species that are suitable for cancer treatment and the genetic engineering systems used to increase their effectiveness for this purpose.

\section{SELECTIVE TARGETING OF CANCER BY BACTERIAL AGENTS}

Tumors are characterized by an altered set of molecular and physiological conditions resulting from the expression of oncogenes by cancer cells and the direct consequences of unregulated cellular division on the host tissue. Solid tumors are therefore associated with their own tumor microenvironment (TME), a heterogenous cellular niche that favors the proliferation of tumor cells and exhibits a distinct metabolic profile that can be used to identify tumor presence. In particular, tumors often grow faster than the blood vessel network that surrounds them, leading to low oxygen concentrations, nutrient deprivation and increased acidity in the TME [9-11]. Each of these effects can be used to selectively target tumors while minimally damaging the surrounding tissue; however, these properties may also interfere with the function of antitumor agents, as the low-oxygen conditions interfere with the generation of reactive oxygen species during radiotherapy and the lack of adequate vascular supply limits the entry of therapeutic chemicals into the tumor. The resistance of cancer cells to conventional treatment is further enhanced by the ability of the TME to stimulate angiogenesis and locally suppress the immune system, facilitating the generation of aggressive cancer phenotypes.

Consequently, TME targeting and tumor cell infiltration is of considerable importance for cancer therapy, and a great number of delivery vesicles based on liposomes, dendrimers, hydrogels, supramolecular assemblies, metal particles and other nanomaterials have been developed for this purpose. These carrier systems typically localize in tumor sites with the help of antibodies or other molecular targeting agents; however, alternative approaches that utilize the distinct physiological features of the TME have also been reported in the literature: hypoxia- or pH-activated drug carriers, for example, selectively deposit their cargo in tumor sites due to the low-oxygen, highcarbonic acid profiles of these regions. Bacteria with antitumor activities fundamentally belong to this second group, as their propensity to target tumor environments stems from the anoxic, immuno- 
privileged nature of the TME, which makes it ideal for the growth of pathogenic or opportunistic anaerobes. As such, bacteria that have been reported to infiltrate tumors are typically anaerobic or facultatively anaerobic [9].

Several reasons exist for using these bacteria for cancer treatment over conventional drug delivery vesicles, principal among which are the self-motility and tumor-targeting capabilities that are inherent to bacterial agents and can be further augmented by the expression of therapeutic proteins $[8,12]$. Furthermore, bacteria can assist the immune cells in recognizing and killing tumor cells prior to metastasis [13], and can easily be eliminated from the body by antibiotic treatment at the end of the therapy [8]. While the TME normally suppresses the immune system, prevents apoptosis and enhances angiogenesis at the tumor site [14], bacterial cells can assist in the recognition of tumor cells by stimulating the host immune response, recruiting immune cells $(e . g$. macrophages, neutrophils and lymphocytes) to the tumor site and reversing the immunosuppressive properties of the TME $[1,8,9]$. For instance, endotoxins from gram-negative bacteria can trigger the secretion of TNF $\alpha$ (tumor necrosis factor $\alpha$ ) from immune cells [15] and bacterial presence can likewise induce IFN- $\gamma$ (interferon gamma) production in tumors, thereby activating cytokinemediated pathways to destroy tumor cells [16].

The antitumor activities of bacteria and immune cells have been reported to be synergistic: neutrophils have been shown to be activated against tumor cells by bacteria [17], while bacteria themselves exhibit enhanced antitumor activity in the presence of cytotoxic $\mathrm{T}$ cells (CD8+ T cells) [18]. In addition to modulating the local inflammatory response, bacteria can also function as vectors to deliver cytokines [19] or tumor-specific antigens into antigen-presenting cells, priming the systemic immune response against tumors [20]. Furthermore, bacterial cells can be used to inhibit tumor-supporting processes such as angiogenesis, and their cytotoxicity against non-tumor cells can be avoided by attenuation, ensuring the site-specific growth and toxic activity of the engineered strain [21]. However, pathogenic bacteria do not natively exhibit all of these properties, and must be modified to maximize their antitumor efficiency while minimizing the potential 
complications associated with the administration of pathogenic species into the human body. Biosystems engineering is therefore necessary to produce modified bacteria with the capacity to express therapeutic proteins, toxins or prodrug-converting enzymes at a specific target site [8]. Methods used for this purpose are detailed below.

\section{BIOSYSTEMS ENGINEERING OF BACTERIA WITH ANTITUMOR ACTIVITY}

\section{Modulation of toxicity and immunogenicity}

Salmonella, Clostridium and Bifidobacterium are the most frequently used bacteria for the development of in vivo tumor therapies, while the model bacteria Escherichia and Bacillus are utilized to a lesser extent (Table 1). As Salmonella and Clostridium species typically produce toxins, reducing the virulence of these bacteria to tumor environments or otherwise preventing them from exerting their systemic toxicity is critical for successful antitumor applications. This is typically performed by the attenuation of these bacteria to either eliminate virulence-related genes entirely or to limit their production to the anoxic tumor microenvironment. Low et al., for example, reported that a knockout mutant of the Salmonella $m s b B$ gene, which is involved in lipid A synthesis and TNF- $\alpha$ induction, exhibits a 10000 -fold decrease in virulence while retaining its tumor-inhibitory effects in mice [22]. Likewise, a strain of Clostridium novyi lacking $\alpha$-toxin expression was able to destroy tumor cells and generate a strong antitumorigenic immune response without exhibiting systemic effects when injected to tumor cells [23].

Conversely, the toxin-producing and immune system-activating properties of bacteria may also be enhanced to improve the antitumor response. CD4- and CD8-dependent tumor inhibition was observed in a Salmonella enterica serovar typimurium strain modified to express the chemokine CCL21, while the expression of IL-18 in the same species also created an effective tumor response based on the recruitment of T-cells, NK-cells and granulocytes [24, 25]. S. enterica serovar typimurium expressing the TNF-family protein FasL and Escherichia coli strain K-12 expressing cytolysin A were also used to effectively inhibit the growth of tumors, the former by 
itself and the latter in combination with radiation therapy [26, 27]. In addition, immunogenic agents can be provided in limited doses alongside an attenuated strain to provide greater control over the ensuing immune response: while $m s b B$-deficient Salmonella is capable of inhibiting tumor growth in mice, its ability to colonize human tumors is limited in the absence of a lipid A-mediated TNF- $\alpha$ response, and the tumor-colonization efficiency of the strain can be improved by externally administering lipid A to generate a controlled immune response without systemic effects [28].

Facultative intracellular parasites such as Listeria, Mycobacterium, Yersinia, Shigella and Salmonella are able to infiltrate bulk tumors or other cell types [29-31], and this ability can also be conferred to non-pathogenic bacteria: Laboratory strains of $E$. coli have been modified with the Yersinia pseudotuberculosis invasin gene to selectively enter immune cells following oral administration, and further modifications may allow these modified bacteria to serve as antigenpresenting agents $[32,33]$. The tumor-specificity of invasive bacteria can also be improved by hypoxia-responsive elements; as low oxygen concentrations are one of the primary hallmarks of solid tumors. Non-pathogenic Clostridium strains have been engineered to produce a single chain antibody that inhibits HIF-1 $\alpha$, a regulatory transcription factor of tumor cells, in response to the hypoxia [34]. Likewise, a pro-apoptotic protein (TRAIL), expressed under control of a hypoxiainducible (nirB) promoter in Salmonella, has been reported to show promise in mouse melanoma models [35, 36]. Clinical trial studies for VNP20009 (genetically attenuated Salmonella; msbB-, purl-) proved to be effective at localizing at the tumor site, shows immune activation and is safe enough for use as a vaccine; however, phase II clinical studies are necessary to further demonstrate its effectiveness in humans [37].

\section{In situ drug activation and antigen secretion}

Bacteria can also be introduced alongside a prodrug to facilitate its activation directly at the tumor site, which of considerable advantage for drugs with short plasma half-lives or severe side effects. Herpes simplex thymidine kinase (HSV1-TK) and E. coli cytosine deaminase (CD) systems are the most popular enzymes for this approach, the former phosphorylating Ganciclovir into 
Ganciclovir triphosphate and the latter cleaving 5-fluorocytosine into 5-fluorouracil [38]. S.enterica serovar typimurium strains engineered with herpes simplex thymidine kinase were shown to be effective in the treatment of melanoma-bearing mice, while the spores of $C$. sporogenes transformed with the E. coli $\mathrm{CD}$ enzyme were able to reduce tumor formation to a greater extent than 5-fluorouracil itself when administered with 5-fluorocytosine, the non-toxic prodrug of this molecule [39, 40]. The purine nucleoside phosphorylase/6-methylpurine 2'-deoxyriboside (PNP/6MePdR) system was also used for the treatment of melanomas in the mouse model [41]. In addition to prodrug converting enzymes, proteins or protein fragments that exhibit drug activity in themselves can also be expressed in tumor-colonizing bacteria: Salmonella and Bifidobacterium strains have been modified to produce endostatin, a well-established anti-angiogenic agent that facilitates tumor shrinkage by inhibiting the formation of blood vessels at the tumor periphery, thereby blocking the supply of oxygen and nutrients into cancer cells $[42,43]$.

CB1954 is another prodrug for the treatment of cancer and can be converted into its toxic form by the activity of nitroreductase (NTR) enzymes. The activation of this prodrug was tested on human colorectal carcinoma-injected nu/nu mice with the co-administiration of NTR-expressing Clostridium sporogenes, which was able to significantly reduce tumor volume following repeated treatment [44]. DNA and RNA-based agents can also be delivered through tumor-invading bacteria, which eliminates the problems associated with the short plasma half-lives inherent to these drugs. Salmonella engineered with a short hairpin RNA (shRNA) that silences the immusuppressive molecule STAT3 was able to improve the effectiveness of conventional vaccines against highly immunosuppressive cancer cells [45]. In addition to vaccine therapy, the efficiency of the antiangiogenic peptide endostatin can also be increased through co-delivery with shRNAs: attenuated Salmonella enterica serovar typhimurium have been engineered to produce endostatin and a shRNA specific to STAT3 and shown to synergistically inhibit metastasis in mouse tumors [44]. 
Tumor-colonizing bacteria typically trigger a local immune response that may assist in the recognition of cancer cells, and this effect can be further enhanced if the resident bacteria also secrete tumor-associated antigens. These so-called "live vaccines" are advantageous in that they are able to directly deliver their cargo into the target site, bypassing the immune privilege of the tumor microenvironment. Two pathways exist for the internalization of bacterial antigens: Bacteria may be phagocytosed by immune system cells, escape the phagocytotic machinery and secrete their antigen within the cytosol, or deliver their cargo on or inside target cells through the type 3 secretion system, which is ordinarily used for the delivery of toxins. Either way, the antigen of interest is delivered to an antigen presenting cell, which will then affect the production of an immune response. In addition to the delivery of bacteria-produced antigens, this method can also be used to introduce the cDNA of an antigen into the body, allowing its production (and subsequent immune recognition) within the cells of the host [46].

Although tumor cells are associated with the overexpression of certain antigens, these are ordinarily not recognized by the immune system. Live vaccines are able to reverse this effect by directly presenting immune cells with tumor antigens, bypassing the immunosuppressive properties of the tumor environment. c-Raf, a serine-threonine kinase of the Raf family, is an example of such an antigen, and a Salmonella enterica serovar typhimurium strain (aroA SL7207) expressing c-Raf antigen was able to reduce Raf-induced lung adenoma growth in mice [47]. In addition, since bacteria are able to express multiple proteins in tandem, the immunostimulatory effects of the secreted antigens can be enhanced through the co-expression of adjuvant proteins. Such an approach has been tested by Fensterle et al. by using a recombinant S. enterica serovar typhimurium aroA SL7207 strain, which co-expresses a tumor-associated antigen (PSA) and an adjuvant protein $(\mathrm{CtxB})$ and allowed the efficient prevention of prostate tumors in mice [48]. More recent studies have also used recombinant strains of bacillus Calmette-Guérin (rBCG) [49], S. enterica serovar typhimurium LB5000 and attenuated S. typhimurium SL3261 [50], and Listeria monocytogenes [51] as live cancer vaccines. 


\section{Bacterial imaging and multi-modal approaches}

The ability of anaerobic bacteria to target tumor tissues can also be used for tumor diagnostics through their transformation with reporter genes. Both primary and metastatic tumors have been visualized under in vivo conditions using light-emitting proteins such as GFP and luciferase, expressed in bacteria such as E. coli, S. enterica, Vibrio cholerae and L. monocytogenes. The safety of these bacteria have also been enhanced by attenuation and, in S. enterica serovar typhimurium A1, auxotrophic dependence on the amino acids found in the tumor environment, which ensures that the bacteria can proliferate only within the TME [52-54]. Magnetotactic bacteria can also colonize tumors and enhance MRI imaging through the magnetite crystals they contain: Magnetospirillum magneticum, for example, was shown to enhance the T1-weighted imaging of solid tumors derived from human embryonic kidney cells in the mouse model [55]. Similarly, $S$. enterica serovar typhimurium VNP20009-TK, an attenuated strain expressing HSV1-TK, was able to localize to tumors and accumulate the radioactive nucleoside analogue 2'-fluoro-1-beta-Darabino-furanosyl-5-iodo-uracil (FIAU) by converting it into FIAU-PO ${ }_{4}$, which is unable to pass through the cell membrane and allows the highly sensitive PET imaging of the tumor site [56].

The synergistic use of multiple methods can further increase the efficiency of treatment and eliminate potential issues with metastasis and relapse, while the inclusion of imaging modalities into treatment options can also allow physicians to make better-informed decisions. This form of approach, called theranostics or multi-modal therapy, is especially common with nanomaterials, which can be functionalized with several distinct targeting, imaging and therapeutic molecules. However, similar methods are also applicable to bacteria, which can be modified to express multiple genes for enhanced tumor invasion, immune response activation, anticancer activity and imaging capacity (Figure 1). A combination of the Yersinia invasin gene and two genetic sensory systems ( $f d h F$ and $a r a B A D$, inducible by low-oxygen conditions and arabinose), for example, has been used to produce a strain of $E$. coli that can invade cells under hypoxia or in the presence of a co-delivered chemical. The same bacterium was also modified with a quorum sensing system 
(Vibrio fischeri lux quorum sensing circuit) that ensures that invasion will occur only after a sufficient number of cells have localized to the tumor tissue [57]. Another environmental factordependent expression circuit was developed on a Bifidobacterium strain, in which the expression of E. coli $\mathrm{CD}$ enzyme was modulated by salicylate-activated regulator elements (the gene $x y l S 2$ and the $x y l S 2$-dependent promoter $\mathrm{Pm}$ ). $\mathrm{CD}$ expression and 5-fluorocytosine-to-5-fluorouracil conversion occurs only in the presence of acetyl salicylic acid, allowing cells to exhibit antitumor activity following the administration of this compound [58].

\section{CONCLUSION}

The administration of pathogenic bacteria into the human body is obviously a dangerous prospect; however, the risks posed by aggressive cancers and the lack of options for their treatment already necessitate the use of therapies with severe side effects. In addition, bioengineering can be utilized to minimize the dangers associated with human pathogens while retaining or enhancing their capacity to eliminate tumor tissue, creating treatments with greater specificity and higher safety than current chemo- and radiotherapy options. While such methods are currently limited to proof-of-concept demonstrations and pre-clinical studies, they would be greatly advantageous for the treatment of solid tumors and especially skin and gastrointestinal tract cancers, as these regions are already densely colonized by native microfauna. Indeed, probiotic bacteria are prime candidates for the engineering of novel bacterial treatments, as probiotic bacteria are already known to protect the gastrointestinal system against tumors and prevent the growth of existing tumors. The use of anaerobes also reduces the risk of systemic infection in the bacterial treatment of solid tumors, and genetic switches can be used to ensure that injected bacteria survives and produces toxins only in the presence of cancer cells. Combined treatments that either deliver bacteria in tandem with conventional anticancer therapies or modulate the secretion of multiple therapeutics may also reduce the risk of cancer recurrence and metastasis by delivering two or more highly toxic agents directly into the tumor site. 


\section{Acknowledgements}

E. Kalyoncu and A. D. Ozkan acknowledge TUBITAK BIDEB 2211 National PhD scholarships. T. T. Olmez and O. F. Sarioglu acknowledge TUBITAK BIDEB 2211-C National PhD scholarships.

\section{Conflicts of interest}

All co-authors have seen and agree with the contents of the manuscript and there is no financial interest to report. The authors declare no conflict of interest. 


\section{References}

[1] Pawelek J, Low K, Bermudes D. Bacteria as tumour-targeting vectors (vol 4, pg 548, 2003). Lancet Oncology, 2003; 4: 658-658.

[2] Ford TJ, Silver PA. Synthetic biology expands chemical control of microorganisms. Curr Opin Chem Biol, 2015; 28: 20-28.

[3] Coelho JF, Ferreira PC, Alves P, Cordeiro R, Fonseca AC, Góis JR, Gil MH. Drug delivery systems: Advanced technologies potentially applicable in personalized treatments. EPMA J, 2010; 1: 164-209.

[4] Liu D, Zhang N. Cancer Chemotherapy With Lipid-Based Nanocarriers. Critical Reviews in Therapeutic Drug Carrier Systems, 2010; 27: 371-417.

[5] Wong H, Bendayan R, Rauth A, Li Y, Wu X. Chemotherapy with anticancer drugs encapsulated in solid lipid nanoparticles. Advanced Drug Delivery Reviews, 2007; 59: 491-504.

[6] Gindy $M$, Prud'homme R. Multifunctional nanoparticles for imaging, delivery and targeting in cancer therapy. Expert Opinion on Drug Delivery, 2009; 6: 865-878.

[7] Chidambaram M, Manavalan R, Kathiresan K. Nanotherapeutics to overcome conventional cancer chemotherapy limitations. J Pharm Pharm Sci, 2011; 14: 67-77.

[8] Patyar S, Joshi R, Byrav D, Prakash A, Medhi B, Das B. Bacteria in cancer therapy: a novel experimental strategy. Journal of Biomedical Science, 2010; 17.

[9] Lee C. Engineering bacteria toward tumor targeting for cancer treatment: current state and perspectives. Applied Microbiology and Biotechnology, 2012; 93: 517-523.

[10] Brown J, Giaccia A. The unique physiology of solid tumors: Opportunities (and problems) for cancer therapy. Cancer Research, 1998; 58: 1408-1416.

[11] FOLKMAN J, WATSON K, INGBER D, HANAHAN D. INDUCTION OF ANGIOGENESIS DURING THE TRANSITION FROM HYPERPLASIA TO NEOPLASIA. Nature, 1989; 339: 58-61.

[12] Forbes N. Engineering the perfect (bacterial) cancer therapy. Nature Reviews Cancer, 2010; 10: 784793.

[13] Ben-Jacob E. Engineering Trojan-horse bacteria to fight cancer. Blood, 2013; 122: 619-620.

[14] Kundu J, Surh Y. Inflammation: Gearing the journey to cancer. Mutation Research-Reviews in Mutation Research, 2008; 659: 15-30.

[15] Beg A, Baltimore D. An essential role for NF-kappa B in preventing TNF-alpha-induced cell death. Science, 1996; 274: 782-784.

[16] Lee C, Wu C, Shiau A. Toll-like receptor 4 mediates an antitumor host response induced by Salmonella choleraesuis. Clinical Cancer Research, 2008; 14: 1905-1912.

[17] Westphal K, Leschner S, Jablonska J, Loessner H, Weiss S. Containment of tumor-colonizing bacteria by host neutrophils. Cancer Research, 2008; 68: 2952-2960.

[18] Lee C, Hsieh J, Wu C, Hsu H, Shiau A. B cells are required for tumor-targeting Salmonella in host. Applied Microbiology and Biotechnology, 2011; 92: 1251-1260.

[19] Sorenson B, Banton K, Frykman N, Leonard A, Saltzman D. Attenuated Salmonella typhimurium with interleukin 2 gene prevents the establishment of pulmonary metastases in a model of osteosarcoma. Journal of Pediatric Surgery, 2008; 43: 1153-1158.

[20] Saccheri F, Pozzi C, Avogadri F, Barozzi S, Faretta M, Fusi P, Rescigno M. Bacteria-Induced Gap Junctions in Tumors Favor Antigen Cross-Presentation and Antitumor Immunity. Science Translational Medicine, 2010; 2.

[21] Clairmont C, Lee K, Pike J, Ittensohn M, Low K, Pawelek J, Bermudes D, Brecher S, Margitich D, Turnier J, Li Z, Luo X, King I, Zheng L. Biodistribution and genetic stability of the novel antitumor agent VNP20009, a genetically modified strain of Salmonella typhimurium. Journal of Infectious Diseases, 2000; 181: 1996-2002.

[22] Low K, Ittensohn M, Le T, Platt J, Sodi S, Amoss M, Ash O, Carmichael E, Chakraborty A, Fischer J, Lin S, Luo X, Miller S, Zheng L, King I, Pawelek J, Bermudes D. Lipid A mutant Salmonella with suppressed virulence and TNF alpha induction retain tumor-targeting in vivo. Nature Biotechnology, 1999; 17: 37-41.

[23] Roberts N, Zhang L, Janku F, Collins A, Bai R, Staedtke V, Rusk A, Tung D, Miller M, Roix J, Khanna K, Murthy R, Benjamin R, Helgason T, Szvalb A, Bird J, Roy-Chowdhuri S, Zhang H, Qiao Y, Karim B, McDaniel J, Elpiner A, Sahora A, Lachowicz J, Phillips B, Turner A, Klein M, Post G, Diaz L, Riggins G, 
Papadopoulos N, Kinzler K, Vogelstein B, Bettegowda C, Huso D, Varterasian M, Saha S, Zhou S. Intratumoral injection of Clostridium novyi-NT spores induces antitumor responses. Science Translational Medicine, 2014; 6.

[24] Loeffler M, Le'Negrate G, Krajewska M, Reed J. Salmonella typhimurium engineered to produce CCL21 inhibit tumor growth. Cancer Immunology Immunotherapy, 2009; 58: 769-775.

[25] Loeffler M, Le'Negrate G, Krajewska M, Reed J. IL-18-producing Salmonella inhibit tumor growth. Cancer Gene Therapy, 2008; 15: 787-794.

[26] Loeffler M, Le'Negrate G, Krajewska M, Reed J. Inhibition of tumor growth using Salmonella expressing Fas ligand. Journal of the National Cancer Institute, 2008; 100: 1113-1116.

[27] Jiang S, Phan T, Nam T, Nguyen V, Kim H, Bom H, Choy H, Hong Y, Min J. Inhibition of Tumor Growth and Metastasis by a Combination of Escherichia coli-mediated Cytolytic Therapy and Radiotherapy. Molecular Therapy, 2010; 18: 635-642.

[28] Zhang M, Swofford C, Forbes N. Lipid A controls the robustness of intratumoral accumulation of attenuated Salmonella in mice. International Journal of Cancer, 2014; 135: 647-657.

[29] Jantsch J, Chikkaballi D, Hensel M. Cellular aspects of immunity to intracellular Salmonella enterica. Immunol Rev, 2011; 240: 185-95.

[30] Silva MT, Pestana NT. The in vivo extracellular life of facultative intracellular bacterial parasites: role in pathogenesis. Immunobiology, 2013; 218: 325-37.

[31] Cossart P, Kocks C. The actin-based motility of the facultative intracellular pathogen Listeria monocytogenes. Mol Microbiol, 1994; 13: 395-402.

[32] Folcher M, Fussenegger M. Synthetic biology advancing clinical applications. Curr Opin Chem Biol, 2012; 16: 345-54.

[33] Critchley-Thorne RJ, Stagg AJ, Vassaux G. Recombinant Escherichia coli expressing invasin targets the Peyer's patches: the basis for a bacterial formulation for oral vaccination. Mol Ther, 2006; 14: 183-91.

[34] Groot AJ, Mengesha A, van der Wall E, van Diest PJ, Theys J, Vooijs M. Functional antibodies produced by oncolytic clostridia. Biochem Biophys Res Commun, 2007; 364: 985-9.

[35] Chatfield SN, Charles IG, Makoff AJ, Oxer MD, Dougan G, Pickard D, Slater D, Fairweather NF. Use of the nirB promoter to direct the stable expression of heterologous antigens in Salmonella oral vaccine strains: development of a single-dose oral tetanus vaccine. Biotechnology (N Y), 1992; 10: 888-92.

[36] Chen J, Yang B, Cheng X, Qiao Y, Tang B, Chen G, Wei J, Liu X, Cheng W, Du P, Huang X, Jiang W, Hu Q, $\mathrm{Hu}$ Y, Li J, Hua ZC. Salmonella-mediated tumor-targeting TRAIL gene therapy significantly suppresses melanoma growth in mouse model. Cancer Sci, 2012; 103: 325-33.

[37] Karbach J, Neumann A, Brand K, Wahle C, Siegel E, Maeurer M, Ritter E, Tsuji T, Gnjatic S, Old LJ, Ritter G, Jäger E. Phase I clinical trial of mixed bacterial vaccine (Coley's toxins) in patients with NYESO-1 expressing cancers: immunological effects and clinical activity. Clin Cancer Res, 2012; 18: 5449-59.

[38] Corban-Wilhelm H, Hull W, Becker G, Bauder-Wust U, Greulich D, Debus J. Cytosine deaminase and thymidine kinase gene therapy in a Dunning rat prostate tumour model: absence of bystander effects and characterisation of 5-fluorocytosine metabolism with F-19-NMR spectroscopy. Gene Therapy, 2002; 9: 1564-1575.

[39] Pawelek JM, Low KB, Bermudes D. Tumor-targeted Salmonella as a novel anticancer vector. Cancer Res, 1997; 57: 4537-44.

[40] Liu S, Minton N, Giaccia A, Brown J. Anticancer efficacy of systemically delivered anaerobic bacteria as gene therapy vectors targeting tumor hypoxia/necrosis. Gene Therapy, 2002; 9: 291-296.

[41] Chen G, Tang B, Yang B, Chen J, Zhou J, Li J, Hua Z. Tumor-targeting Salmonella typhimurium, a natural tool for activation of prodrug $6 \mathrm{MePdR}$ and their combination therapy in murine melanoma model. Applied Microbiology and Biotechnology, 2013; 97: 4393-4401.

[42] Fu G, Li X, Hou Y, Fan Y, Liu W, Xu G. Bifidobacterium longum as an oral delivery system of endostatin for gene therapy on solid liver cancer. Cancer Gene Therapy, 2005; 12: 133-140.

[43] Lee C, Wu C, Shiau A. Endostatin gene therapy delivered by Salmonella choleraesuis in murine tumor models. Journal of Gene Medicine, 2004; 6: 1382-1393. 
[44] Li X, Li Y, Wang B, Ji K, Liang Z, Guo B, Hu J, Yin D, Du Y, Kopecko D, Kalvakolanu D, Zhao X, Xu D, Zhang L. Delivery of the co-expression plasmid pEndo-Si-Stat3 by attenuated Salmonella serovar typhimurium for prostate cancer treatment. Journal of Cancer Research and Clinical Oncology, 2013; 139: 971-980.

[45] Manuel ER, Blache CA, Paquette R, Kaltcheva TI, Ishizaki H, Ellenhorn JD, Hensel M, Metelitsa L, Diamond DJ. Enhancement of cancer vaccine therapy by systemic delivery of a tumor-targeting Salmonella-based STAT3 shRNA suppresses the growth of established melanoma tumors. Cancer Res, 2011; 71: 4183-91.

[46] Toussaint B, Chauchet X, Wang Y, Polack B, Le Gouellec A. Live-attenuated bacteria as a cancer vaccine vector. Expert Review of Vaccines, 2013; 12: 1139-1154.

[47] Gentschev I, Fensterle J, Schmidt A, Potapenko T, Troppmair J, Goebel W, Rapp U. Use of a recombinant Salmonella enterica serovar Typhimurium strain expressing C-Raf for protection against C-Raf induced lung adenoma in mice. Bmc Cancer, 2005; 5.

[48] Fensterle J, Bergmann B, Yone C, Hotz C, Meyer S, Spreng S, Goebel W, Rapp U, Gentschev I. Cancer immunotherapy based on recombinant Salmonella enterica serovar Typhimurium aroA strains secreting prostate-specific antigen and cholera toxin subunit B. Cancer Gene Therapy, 2008; 15: 8593.

[49] Ding G, Yu Y, Shen Z, Zhou X, Chen S, Liao G, Zhang Y. Antitumor effects of human interferon-alpha $2 \mathrm{~b}$ secreted by recombinant bacillus Calmette-Gu,rin vaccine on bladder cancer cells. Journal of Zhejiang University-Science B, 2012; 13: 335-341.

[50] Ye J, Li L, Zhang Y, Zhang X, Ren D, Chen W. Recombinant salmonella-based 4-1BBL vaccine enhances $T$ cell immunity and inhibits the development of colorectal cancer in rats: in vivo effects of vaccine containing 4-1BBL. Journal of Biomedical Science, 2013; 20.

[51] Kennedy G, Judy B, Bhojnagarwala P, Moon E, Fridlender Z, Albelda S, Singhal S. Surgical cytoreduction restores the antitumor efficacy of a Listeria monocytogenes vaccine in malignant pleural mesothelioma. Immunology Letters, 2015; 166: 28-35.

[52] Zhao M, Yang M, Li XM, Jiang P, Baranov E, Li S, Xu M, Penman S, Hoffman RM. Tumor-targeting bacterial therapy with amino acid auxotrophs of GFP-expressing Salmonella typhimurium. Proc Natl Acad Sci U S A, 2005; 102: 755-60.

[53] Min JJ, Nguyen VH, Kim HJ, Hong Y, Choy HE. Quantitative bioluminescence imaging of tumortargeting bacteria in living animals. Nat Protoc, 2008; 3: 629-36.

[54] Yu YA, Shabahang S, Timiryasova TM, Zhang Q, Beltz R, Gentschev I, Goebel W, Szalay AA. Visualization of tumors and metastases in live animals with bacteria and vaccinia virus encoding light-emitting proteins. Nat Biotechnol, 2004; 22: 313-20.

[55] Benoit MR, Mayer D, Barak Y, Chen IY, Hu W, Cheng Z, Wang SX, Spielman DM, Gambhir SS, Matin A. Visualizing implanted tumors in mice with magnetic resonance imaging using magnetotactic bacteria. Clin Cancer Res, 2009; 15: 5170-7.

[56] Soghomonyan SA, Doubrovin M, Pike J, Luo X, Ittensohn M, Runyan JD, Balatoni J, Finn R, Tjuvajev JG, Blasberg R, Bermudes D. Positron emission tomography (PET) imaging of tumor-localized Salmonella expressing HSV1-TK. Cancer Gene Ther, 2005; 12: 101-8.

[57] Anderson JC, Clarke EJ, Arkin AP, Voigt CA. Environmentally controlled invasion of cancer cells by engineered bacteria. J Mol Biol, 2006; 355: 619-27.

[58] Royo JL, Becker PD, Camacho EM, Cebolla A, Link C, Santero E, Guzmán CA. In vivo gene regulation in Salmonella spp. by a salicylate-dependent control circuit. Nat Methods, 2007; 4: 937-42.

[59] Cronin M, Morrissey D, Rajendran S, El Mashad S, van Sinderen D, O'Sullivan G, Tangney M. Orally Administered Bifidobacteria as Vehicles for Delivery of Agents to Systemic Tumors. Molecular Therapy, 2010; 18: 1397-1407.

[60] Fox ME, Lemmon MJ, Mauchline ML, Davis TO, Giaccia AJ, Minton NP, Brown JM. Anaerobic bacteria as a delivery system for cancer gene therapy: in vitro activation of 5-fluorocytosine by genetically engineered clostridia. Gene Ther, 1996; 3: 173-8.

[61] Toso J, Gill V, Hwu P, Marincola F, Restifo N, Schwartzentruber D, Sherry R, Topalian S, Yang J, Stock F, Freezer L, Morton K, Seipp C, Haworth L, Mavroukakis S, White D, MacDonald S, Mao J, Sznol M, Rosenberg S. Phase I study of the intravenous administration of attenuated Salmonella 
typhimurium to patients with metastatic melanoma. Journal of Clinical Oncology, 2002; 20: 142152.

[62] Lee C, Wu C, Shiau A. Systemic administration of attenuated Salmonella choleraesuis carrying thrombospondin-1 gene leads to tumor-specific transgene expression, delayed tumor growth and prolonged survival in the murine melanoma model. Cancer Gene Therapy, 2005; 12: 175-184.

[63] Li X, Fu GF, Fan YR, Liu WH, Liu XJ, Wang JJ, Xu GX. Bifidobacterium adolescentis as a delivery system of endostatin for cancer gene therapy: selective inhibitor of angiogenesis and hypoxic tumor growth. Cancer Gene Ther, 2003; 10: 105-11.

[64] Theys J, Landuyt W, Nuyts S, Van Mallaert L, Lambin P, Anne J. Clostridium as a tumor-specific delivery system of therapeutic proteins. Cancer Detection and Prevention, 2001; 25: 548-557.

[65] Barbe S, Van Mellaert L, Theys J, Geukens N, Lammertyn E, Lambin P, Anne J. Secretory production of biologically active rat interleukin-2 by Clostridium acetobutylicum DSM792 as tool for anti-tumor treatment. Fems Microbiology Letters, 2005; 246: 67-73.

[66] Theys J, Pennington O, Dubois L, Anlezark G, Vaughan T, Mengesha A, Landuyt W, Anne J, Blurke P, Durre P, Wouters B, Minton N, Lambin P. Repeated cycles of Clostridium-directed enzyme prodrug therapy result in sustained antitumour effects in vivo. British Journal of Cancer, 2006; 95: 12121219.

[67] Yano S, Zhang Y, Zhao M, Hiroshima Y, Miwa S, Uehara F, Kishimoto H, Tazawa H, Bouvet M, Fujiwara T, Hoffman R. Tumor-targeting Salmonella typhimurium A1-R decoys quiescent cancer cells to cycle as visualized by FUCCI imaging and become sensitive to chemotherapy. Cell Cycle, 2014; 13: 39583963.

[68] Hiroshima Y, Zhao M, Zhang Y, Zhang N, Maawy A, Murakami T, Mii S, Uehara F, Yamamoto M, Miwa S, Yano S, Momiyama M, Mori R, Matsuyama R, Chishima T, Tanaka K, Ichikawa Y, Bouvet M, Endo I, Hoffman RM. Tumor-Targeting Salmonella typhimurium A1-R Arrests a Chemo-Resistant Patient Soft-Tissue Sarcoma in Nude Mice. PLoS One, 2015; 10: e0134324.

[69] Hiroshima Y, Zhang Y, Zhao M, Zhang N, Murakami T, Maawy A, Mii S, Uehara F, Yamamoto M, Miwa S, Yano S, Momiyama M, Mori R, Matsuyama R, Chishima T, Tanaka K, Ichikawa Y, Bouvet M, Endo I, Hoffman RM. Tumor-Targeting Salmonella typhimurium A1-R in Combination with Trastuzumab Eradicates HER-2-Positive Cervical Cancer Cells in Patient-Derived Mouse Models. PLoS One, 2015; 10: e0120358.

[70] Jiang SN, Phan TX, Nam TK, Nguyen VH, Kim HS, Bom HS, Choy HE, Hong Y, Min JJ. Inhibition of tumor growth and metastasis by a combination of Escherichia coli-mediated cytolytic therapy and radiotherapy. Mol Ther, 2010; 18: 635-42.

[71] Luo Y, Henning J, O'Donnell MA. Th1 cytokine-secreting recombinant Mycobacterium bovis bacillus Calmette-Guérin and prospective use in immunotherapy of bladder cancer. Clin Dev Immunol, 2011; 2011: 728930.

[72] Clairmont C, Lee KC, Pike J, Ittensohn M, Low KB, Pawelek J, Bermudes D, Brecher SM, Margitich D, Turnier J, Li Z, Luo X, King I, Zheng LM. Biodistribution and genetic stability of the novel antitumor agent VNP20009, a genetically modified strain of Salmonella typhimurium. J Infect Dis, 2000; 181: 1996-2002.

[73] Kochut A, Dersch P. Bacterial invasion factors: tools for crossing biological barriers and drug delivery? Eur J Pharm Biopharm, 2013; 84: 242-50.

[74] You L, Cox RS, Weiss R, Arnold FH. Programmed population control by cell-cell communication and regulated killing. Nature, 2004; 428: 868-71.

[75] Yamaguchi Y, Park JH, Inouye M. Toxin-antitoxin systems in bacteria and archaea. Annu Rev Genet, 2011; 45: 61-79.

[76] Bassler B. How bacteria talk to each other: regulation of gene expression by quorum sensing. Current Opinion in Microbiology, 1999; 2: 582-587.

[77] Solano C, Echeverz M, Lasa I. Biofilm dispersion and quorum sensing. Current Opinion in Microbiology, 2014; 18: 96-104.

[78] Liu S, Xu X, Zeng X, Li L, Chen Q, Li J. Tumor-targeting bacterial therapy: A potential treatment for oral cancer (Review). Oncol Lett, 2014; 8: 2359-2366. 
Table 1. Selective targeting of tumors by bacteria

\begin{tabular}{|c|c|c|c|}
\hline $\begin{array}{l}\text { Tumor Targeting } \\
\text { Bacteria }\end{array}$ & Modification & Tumor Model & References \\
\hline Bifidobacterium breve & Exression of lux gene & Murine B16 melanoma & {$[59]$} \\
\hline $\begin{array}{l}\text { Bifidobacterium } \\
\text { longum }\end{array}$ & Expression of endostatin gene & $\begin{array}{l}\text { HepG2 human liver cancer, } \\
\text { Yac-1 mouse lymphoma, } \\
\text { L929 human fibre cell }\end{array}$ & {$[42]$} \\
\hline $\begin{array}{l}\text { Clostridium } \\
\text { beijerinckii }\end{array}$ & $\begin{array}{l}\text { Expression of pro-drug } \\
\text { converting enzyme CD }\end{array}$ & Murine EMT6 carcinoma & {$[60]$} \\
\hline $\begin{array}{l}\text { Salmonella enterica } \\
\text { serovar typhimurium }\end{array}$ & $\begin{array}{l}\text { Attenuation by chromosomal } \\
\text { deletion of the purI and } m s b B \\
\text { genes }\end{array}$ & $\begin{array}{l}\text { Clinical trial (metastatic } \\
\text { melanoma and metastatic } \\
\text { renal cell carcinoma) }\end{array}$ & {$[61]$} \\
\hline $\begin{array}{l}\text { S. enterica serovar } \\
\text { typhimurium } 14028\end{array}$ & Expression of HSV-TK gene & Murine B16 melanoma & [39] \\
\hline $\begin{array}{l}\text { S. enterica serovar } \\
\text { typhimurium }\end{array}$ & Expression of IL-2 gene & Murine K7M2 osteosarcoma & [19] \\
\hline $\begin{array}{l}\text { S. enterica serovar } \\
\text { typhimurium }\end{array}$ & $\begin{array}{l}\text { Expression of STAT3-specific } \\
\text { shRNA }\end{array}$ & Murine B16 melanoma & {$[45]$} \\
\hline $\begin{array}{l}\text { Salmonella } \\
\text { choleraesuis }\end{array}$ & Expression of endostatin gene & $\begin{array}{l}\text { Murine MBT- } 2 \text { bladder } \\
\text { cancer, MBT-2 bladder tumor, } \\
\text { ML-1 hepatoma }\end{array}$ & {$[43]$} \\
\hline S. choleraesuis & Expression of TSP-1 gene & Murine B16 melanoma & {$[62]$} \\
\hline $\begin{array}{l}\text { Bifidobacterium } \\
\text { adolescentis }\end{array}$ & Expression of endostatin gene & Murine Heps liver cancer & {$[63]$} \\
\hline $\begin{array}{l}\text { Clostridium } \\
\text { acetobutylicum }\end{array}$ & $\begin{array}{l}\text { Expression of mTNF- } \alpha \text { and } \\
\text { E. coli } \mathrm{CD}\end{array}$ & Rat rhabdomyosarcoma R1 & {$[64]$} \\
\hline $\begin{array}{l}\text { Clostridium } \\
\text { sporogenes }\end{array}$ & Expression of E. coli CD & SCCVII tumours in mice & [40] \\
\hline C. acetobutylicum & Expression of IL-2 gene & Rat rhabdomyosarcoma & {$[65]$} \\
\hline $\begin{array}{l}\text { C. sporogenes and } \\
\text { Clostridium novyi-NT }\end{array}$ & $\begin{array}{l}\text { Expression of pro-drug } \\
\text { converting enzyme NTR }\end{array}$ & $\begin{array}{l}\text { Human colorectal } \\
\text { carcinoma (HCT116) }\end{array}$ & {$[66]$} \\
\hline $\begin{array}{l}\text { S. enterica serovar } \\
\text { typhimurium } \mathrm{A} 1-\mathrm{R}\end{array}$ & $\begin{array}{l}\text { Making quiescent tumor cells } \\
\text { susceptible to cytotoxic agents }\end{array}$ & $\begin{array}{l}\text { Quiescent MKN45 stomach } \\
\text { adenocarcinoma in mice }\end{array}$ & {$[67]$} \\
\hline $\begin{array}{l}\text { S. enterica serovar } \\
\text { typhimurium A1-R }\end{array}$ & $\begin{array}{l}\text { Making quiscent tumor cells } \\
\text { susceptible to cytotoxic agents }\end{array}$ & $\begin{array}{l}\text { Human soft-tissue sarcoma } \\
\text { growing in nude mice }\end{array}$ & {$[68]$} \\
\hline $\begin{array}{l}\text { S. enterica serovar } \\
\text { typhimurium A1-R }\end{array}$ & $\begin{array}{l}\text { Making quiescent tumor cells } \\
\text { susceptible to cytotoxic agents }\end{array}$ & $\begin{array}{l}\text { Human HER-2 positive } \\
\text { cervical cancer in nude mice } \\
\text { model }\end{array}$ & [69] \\
\hline $\begin{array}{l}\text { Salmonella enterica } \\
\text { serovar typhimurium }\end{array}$ & $\begin{array}{l}\text { Co-expression of endostatin and } \\
\text { STAT3-specific shRNA }\end{array}$ & $\begin{array}{l}\text { RM-1 mouse prostate cancer } \\
\text { cell line }\end{array}$ & {$[44]$} \\
\hline Escherichia coli $\mathrm{K}-12$ & Expression of $C l y A$ & Murine CT26 colon cancer & {$[70]$} \\
\hline $\begin{array}{l}\text { Mycobacterium bovis } \\
\text { bacillus Calmette- } \\
\text { Guérin (BCG) }\end{array}$ & Expression of Th1 cytokines & $\begin{array}{l}\text { Human bladder cancer cell } \\
\text { lines (T24, J82, 5637, } \\
\text { TCCSUP and UMUC-3) }\end{array}$ & {$[71]$} \\
\hline
\end{tabular}




\begin{tabular}{|c|c|c|c|}
\hline $\begin{array}{c}\text { S. enterica } \text { serovar } \\
\text { typhimurium }\end{array}$ & $\begin{array}{l}\text { Expression of } \\
\text { immunostimulatory } \\
\text { cytokine, CCL21 }\end{array}$ & $\begin{array}{l}\text { Multi-drug-resistant CT26 } \\
\text { colon carcinoma, D2F2 } \\
\text { breast carcinoma and B16 } \\
\text { melanoma in mice }\end{array}$ & [24] \\
\hline $\begin{array}{l}\text { S. enterica serovar } \\
\text { typhimurium }\end{array}$ & $\begin{array}{l}\text { Expression of proapoptotic } \\
\text { cytokine, FasL }\end{array}$ & $\begin{array}{l}\text { Murine D2F2 breast } \\
\text { carcinoma and CT-26 colon } \\
\text { carcinoma }\end{array}$ & [26] \\
\hline $\begin{array}{c}\text { S. enterica } \text { serovar } \\
\text { typhimurium }\end{array}$ & Expression of IL-18 & $\begin{array}{l}\text { Multi-drug resistant murine } \\
\text { CT26 colon carcinoma and } \\
\text { D2F2 melanoma }\end{array}$ & [25] \\
\hline $\begin{array}{l}\text { S. enterica serovar } \\
\text { typhimurium } \\
\text { aroA SL7207 }\end{array}$ & $\begin{array}{l}\text { Expression of a fusion } \\
\text { protein of PSA and CtxB }\end{array}$ & Murine prostate cancer & [48] \\
\hline $\begin{array}{l}\text { S. enterica serovar } \\
\text { typhimurium } \\
\text { aroA SL7207 }\end{array}$ & Expression of c-Raf antigen & Murine lung adenoma & [47] \\
\hline E. coli & $\begin{array}{l}\text { Expression of inv under the } \\
\text { control of the quorum sensing } \\
\text { lux operon }\end{array}$ & $\begin{array}{l}\text { HeLa, HepG2, and U2OS } \\
\text { cell lines }\end{array}$ & [57] \\
\hline $\begin{array}{l}\text { S. enterica serovar } \\
\text { typhimurium } \\
\text { VNP20009 }\end{array}$ & $\begin{array}{l}\text { Attenuation by chromosomal } \\
\text { deletion of the purI, } x y l \\
\text { and } m s b B \text { genes with an } \\
\text { increased resistance to } \\
\text { EGTA }\end{array}$ & $\begin{array}{l}\text { B16-F10 murine melanoma, } \\
\text { LOX human melanoma } \\
\text { and DLD-1 human } \\
\text { colon } \\
\text { carcinoma }\end{array}$ & [72] \\
\hline
\end{tabular}

lux, luciferase; CD, cytosine deaminase; HSV-TK, herpes simplex virus thymidine kinase; IL, interleukin; STAT3, signal transducer and activator of transcription 3; shRNA, short hairpin RNA; TSP-1, thrombospondin-1; TNF- $\alpha$, tumor necrosis factor- $\alpha$; NTR; nitroreductase; ClyA, Cytolysin A; FasL, FAS ligand; CCL21, collagen crosslinking 21; PSA, prostate-specific antigen; CtxB, cholera toxin subunit $\mathrm{B}$; inv, invasin 


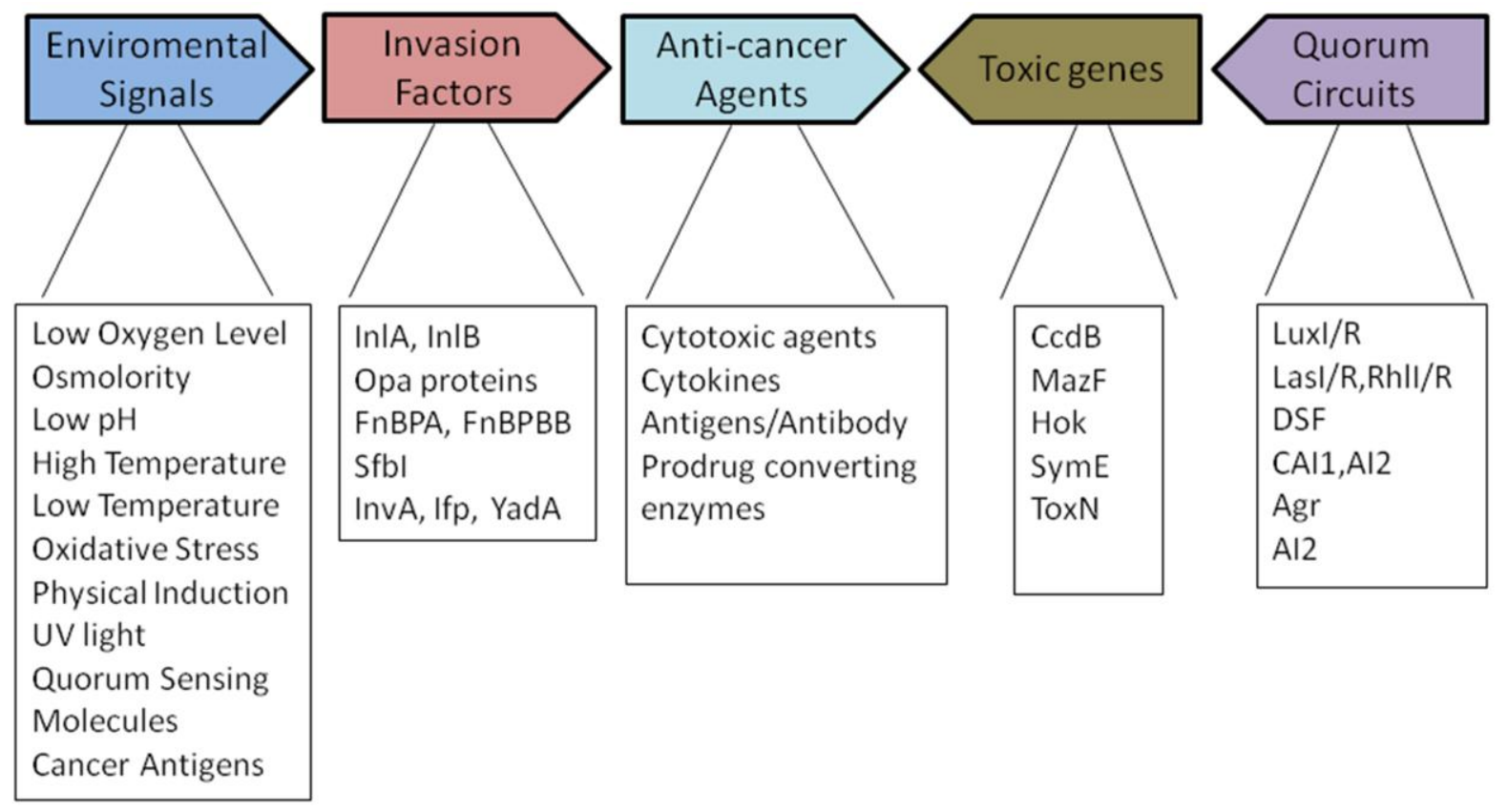

Fig. 1 Genetic elements used in the engineering of tumor-killing bacteria [73-78]. (Inl: Internalin; Opa: Opacity-associated proteins; Fn: Fibronectin; FnBP: Fibronectin-binding protein; SfbI: $S$. pyogenes fibronectin-binding protein I; InvA: Invasin A; YadA: Yersinia adhesin A) 